\title{
Din Öğretiminde Yeni Yöntem Arayışları Uluslarası Sempozyumu*
}

\author{
Sönmez KUTLU \\ Doç. Dr., Ankara Üniversitesi İlâhiyat Fakültesi \\ e-mail: skutlu@divinity.ankara.edu.tr
}

Laik bir devlette, yaygın ve örgün eğitimde din eğitiminin yeri, devlet eliyle verilip verilemeyeceği, zorunlu ya da seçmeli olması, din eğitimi verildiği takdirde hangi yaşlarda başlanacağı, nelerin öğretileceği ve benzeri sorunlar, Türkiye'de en çok tartışllan konuların başında gelmektedir. 1982 yılına kadar, daha çok, Din eğitiminin varlığı-yokluğu tartışılırken, bu tarihten sonra, Anayasal güvence altına alınmasıyla birlikte, Din Kültürü ve Ahlak Bilgisi adı altında ilkokul IV. sınıftan itibaren zorunlu bir ders olarak okul programlarında yerini almıştır. Din eğitiminden çok, din kültürünün ve ahlak bilgisinin öğretilmesini hedefleyen bu yeni durum, Anayasa'ya girmesiyle, en az diğer maddeler kadar yasal bir meşruiyet kazanmıştır. Son yirmi yıldır, Din Kültürü ve Ahlak Bilgisi derslerinin zorunluluğu ve içeriği, bazı kesimlerin eleştirilerine uğramışsa da, genelde kamuoyunun desteğini ve güvenini kazanmıştır. Böylece Din eğitimi, varlık tartışmalarından kurtulmuş ve özgürlüğüne kavuşmuştur. Ancak bu dönemin hassasiyeti içerisinde hazırlanan müfredat programları ve yazılan kitaplar, bir yıl öncesine kadar yürürlükte kalmış ve bu derslerin öğrenciler ve toplum

*Düzenlcyen: Din Öğretimi Genel Müdürlüğü Tarih: 28-30 Mart 2001 Istanbul 
üzerinde nasıl bir değişim ve dönüşüme sebep olduğu, bu derslerde öğrencilerin beklentilerine ve sosyal hayattaki ihtiyaçlarına ne kadar cevap verilebildiği, Din Kültürü ve Ahlak Bilgisi derslerinin öğretiminde kullanılan metodların olumlu ve olumsuz yönlerinin neler olduğu üzerine ciddi bilimsel araştırmalar ve analizler oldukça sınırlı düzeyde yapılabilmiştir. Bununla birlikte, Din Öğretimi Genel Müdürlüğün'de kurulan bir komisyonun bir kaç yıldan beri çalışarak, bu derslerin müfredat programını yeniden belirlemiş olması, Din Eğitimi ile ilgili problemlerin çözümü için atılan ciddi adımlardan birisi olarak kabul edilebilir.

Bireysel, toplumsal ve evrensel bir olgu olan dinin, nasil ve hangi model esas alınarak öğretileceği konusu, ülkemizin Avrupa Birliğine aday ülke olması süreciyle birlikte, $2000^{\prime} l i$ yıllarda yaşayacağı toplumsal ve kültürel değişim gözönüne alındığında, her zamankinden daha çok önem arzetmektedir. Bu sebeple, Türkiye tarihi ve kültürel birikiminden ve eğitim-öğretim konusunda batıda geliştirilen modellerden istifade ederek, genelde eğitim sitemini, özelde din eğitimini, felsefesi, hedefleri ve toplumsal temelleri bakımından yeniden gözden geçirmek ve bilimsel veriler ışı̆̆ında bazı reformlar yapmak durumundadır.

"Küreselleşen", "çok kültürlü" ve "çok dinli" bir dünyada dinin nasıl öğretilmesi gerektiği konusunda, akademik çevrelerde "Dinlerarası", "Fenomenolojik", "Din ya da Mezhep Merkezli" ve "Sorgulayıcı" olmak üzere bir çok model geliştirilmiş bulunmaktadır. Bütün bu modellerin geliştirilmesindeki amaç, çok dinli ve çok kültürlü toplumların din eğitimi ve öğretimi konusundaki bilgi açığını ve ihtiyacını karşılamaktır. Hiç kuşkusuz, farklı toplumsal yapılar ve farklı dinlerin öğretimi için üretilen bu metodların, ülkemize aynen taşınması veya İslam'ın öğretilmesi için aynen kullanılması mümkün değildir. Ancak, batıda din öğretimi konusunda uzman olan bilim adamlarınca geliştirilen bu modellere kayıtsız kalmamız da düşünülemez.

Din Öğretimi Genel Müdürlüğü, din öğretiminin varlık sorunu tartışmalarını geride bırakarak 2000'li yıllarda din öğretiminde yeni bir yöntem arayışına girmiş ve bu amaçla "Din Öğretiminde Yeni Yöntem Arayışları "adlı uluslararası bir sempozyum düzenlemiştir.' Ülkemizde dinin daha iyi ve doğru bir şekilde hangi modelle verilmesi gerektiğinin tespiti projesinin ilk adımı olarak, bu konuda batı dünyasında geliştirilen modelleri, bu modellerin sosyal, psikolojik, teolojik ve felsefi temelleri, uygulamada görülen aksaklıkları ve bunların çozüm yolları sayıları otuzbeşi aşan yerli ve yabancı bilim adamının tartışmaşna açmıştır.

Sempozyum, Açılış ve Protokol Konuşmaları ile Genel Değerlendirme Oturumu hariç olmak üzere, toplam beş oturumdan oluşmuştur. Üç gün

' Scmpozyum düzenleme kurulu şu üyelerden oluşmaktadır: Prof. Dr. Mualla Selçuk (Başkan), Prof. Dr. Recep Kılıç (II. Başkan), Doç. Dr. Sönmez Kutlu (Sekreter), Ersin Marashoğlu (Sekreter), Prof. Dr. Cemal Tosun, Doç. Dr. Recai Doğan, Muammer Kandemir, Mehmet Çatakçı, Yüksel Kaymakoğlu. 
devam eden sempozyumun açılış konuşmasını yapan Din Öğretimi Genel Müdürü Prof. Dr. Mualla Selçuk, konuşmasında dinin doğru ve bilimsel metotlarla ögretilmesinin önemini, sempozyumun düzenlenme amacını ve ele alınacak konular üzerinde durarak üç gün sürecek oturum ve tartışmalarda şu soruların cevabının aranacağını söyledi: " Günümüz insanı din̂̂ metinlerle nasıl bir iletişim veya bildirişim gerçekleştirebilir ? Bugünkü bilinç çatımızla dinsel olgu ve olaylara nasıl bakmalıyız? Geçmişle (tarihimiz) şimdi (çağdaş evrensel değerler) arasında işlek bir köprü kurmamızı sağlayacak yöntemleri nasıl geliştirebiliriz? "Sempozyumun amacının öğrencilerin psikolojik öğrenme yaşlarına uygun yaklaşım biçimlerinin belirlenmesi olduğunu söyleyen Selçuk, yaklaşım biçiminden neyin kastedildiğini şu şekilde açıkladı: " Yaklaşım biçimi, sadece gelişim basamaklarına değil, elbette sosyo-kültürel doku ve sahip olunan din anlayışına bağlıdır. Sağlıklı din eğitimi, kaliteli eğitim ve öğretimden geçer. Dünya barışa muhtaç olduğundan dinlerarası barışa ihtiyaç var. Dinlerarası barış, dinlerarası diyalogu gerektirir. Dinlerarası diyalog ise, dinlerde temel araştırmalar yapmayı gerektirir. Bütün bunlar ise eğitim ve öğretim alanında çabaların artınlmasını zorunlu kılar."

Daha sonra Türkiye'deki semavî dinlerin temsilcileri birer konuşma yaptılar. Musevî Haham Başı Vekili İshak Haleva, din eğitiminin ehil olmayan ellere teslim edilmesinin yarardan çok zarar getireceğini belirttikten sonra şöyle dedi: "Eğitimin bence çok önemli ve ayrılmaz bir parçası olan dinsel eğitime, çağdaş bilimle bir bütünlük içerisinde işlerlik kazandırmak temel amaç olmalıdır. Semavî din kurumu çağdaşlığa engel değil, bilhassa çağdaşlığı telkin eden bir kurumdur." Rum Patriği Patrik Bartolomeos ise, ahlaklı ve temiz insanlar yetiştirmenin, eğitimin ve öğretimin birinci hedefi olması gerektiğini vurguladı. Okullarda ahlâk derslerinin yanında din derslerinin de bulunması gerektiğini savunan Bartolomeos, din dersi kitaplarının diğer dinler aleyhinde yazılanlardan arındırılmasının elzem oldugunu söyledi ve şunları ekledi: "Tüm yaratılanların tek olan yaratıcının eseri olduğunu öğretmek ve diğer dinlere sevgi, saygı ile bakılmasını sağlamak hedef olmalıdır. Din derslerinde ögrencinin not korkusu olmamalıdır. Öğretmenlerin bağnazlıktan uzak olması en önemli eğitim aracidır."

Diyanet İşleri Başkanı Mehmet Nuri Yılmaz, dinin insanlık tarihindeki önemi ve doğru öğretilmesinin gereğini dile getiren bir konuşma yaptı. Yılmaz, şu anda tartışmanın odak noktasında yer alan Kur'an kursları probleminin çözümü ile ilgili olarak daha önce bir çok kimsenin gündeme getirdiği şu öneriyi tekrarladı: "İlköğretim 6., 7. ve 8. sınıflarına, isteğe bağlı Kur'an'ı Kerim ve Meâli dersi konulmalıdır. Bu bir ihtiyaçtır. Bu gerçekleşirse Kur'an kurslarına büyük ölçüde ihtiyaç duyulmayabilir." Bu teklif, her nedense, basın tarafından, ilk defa söylenen bir şeymiş gibi algılanarak Sempozyum'da üç gün boyunca tartışılan hayatî problemler görmezlikten gelinmiştir. 
Milli Eğitim Bakanı Metin Bostancıŏglu, yaptığı konuşmada, 2000'li yıllarda yaşanacak sosyal değişim ve $A B$ sürecinin, Türkiye'de din öğretimi anlayışının ve uygulamasının gözden geçirilmesini zorunlu kıldığını ve Türkiye'nin sosyo-kültürel alandaki hızlı değişim ve gelişim ışığında din öğretimi modelinin yeniden ele alınması amacıyla böyle bir sempozyumu düzenlediklerini bildirdi. Bu sempozyumun, Türkiye'deki din öğretiminin problemlerini çözme konusunda önemli katkılarda bulunacağına inandığını ifade eden Bostancioğlu, sözlerini şöyle sürdürdü: "Dinin toplumsal ve bireysel yaşamı yakından ilgilendiren ahlâkî öğretileri arka plana itilerek, şekilcilik ve sloganların öne çıkarıldığı bir ortamda, gerçek ve sağlıklı bir din öğretimi daha da önem kazanmaktadır. Akla ve bilime dayalı bir din anlayışı kaliteli öğretimle mümkündür. Din doğru öğretilmezse, insanları bağnazlığa ve fanatizme götürür. Bunun sonucunda Allah ve Peygamber adına hareket edenler, kendilerinde yargılama yetkisi görenler türeyebilir. Tarih bunun sayısız örnekleriyle doludur. Asıl tehlike, insanların kendilerine sunulan bu tür dinî anlayışları, gerçek din gibi kabul etmeleri durumunda başlar. Din eğitimcileri, bireyleri böyle bir din anlayışına mahkum etmemek için ellerinden gelen çabayı göstermek zorundadırlar." Milli Eğitim Bakanı Bostancıoğlu, sempozyumun Türkiye ve bütün ülkeler açısından önemli ve yararlı sonuçlar getireceğine inandığını belirterek emeği geçen herkese teşekkür etti ve başarılar diledi.

Öğleden sonra ise, tebliğlerin sunulup tartışıldığı oturumlara geçildi. Üç gün süren sempozyumda beş ayrı oturumda sırayla şu konular tartışıldı:

\section{I.Oturum: Avrupa Topluluğu: Çoğulcu Toplum ve Din Öğretimi}

Çoğulcu toplumda Din eğitiminin felsefì, toplumsal, teolojik ve diğer temellerinin tartışıldığı ve MEB Müsteşarı Bener Cordan'ın başkanlığını yaptığ 1 bu oturumda ilk bildiriyi, Ingiltere Birmingham Üniversitesi'nden katılan Din eğitimcisi Prof. Dr. John M. Hull sundu. Tebliğine, din eğitimi modeli konusunda Avrupa ve Amerika gibi çoğulcu ve demokratik toplumlar arasında önemli farklılıkların bulunduğunu; tek dinlilikten (monoreligious) çok dinli yaklaşıma kadar geniş bir yelpazede verildiğini belirterek başlayan Hull, din eğitiminin şu üç ayrı biçimde verilebileceği tezini ortaya attı:

a) Dini Öğrenme (Learning Religion): Burada, her bireyin mensubu olduğu dinin prensipleri ve inançlarının öğretilmesi amaçlanır. Bu, bir anlamda, bir tek dinin ya da bir tek teolojik sistemin (Confessional/Indoctrinal) öğretimdir. Bu yaklaşımda, esas olan azınlık guruplarının kendi dinlerini öğrenmeleri ve onların dinlerine saygıdır.

b) Din Hakkında Öğrenme (Learning about Religion): Dinle ilgili araştırma ve çalışmaları içerir. Din bir disiplin olarak öğretilir ve diğer dinlerle karşılaştırmalar yapılmak suretiyle öğretilir. Din öğretiminde geliştirilen Fenomenolojik yaklaşım, din öğretimine bilimsel yaklaşmanın sonucunda geliştirilmiştir. Bu anlamda, Din Eğitimi, Teolojinin bir alt 
disiplini olup farklı dinleri, öğrenme konusunda eşit haklar tanır. İngiltere ve Norveç'te geliştirilen modeller, bu kısma girebilir. Din hakkında öğrenme, çok dinli, çok kültürlü, çoğulcu ve demokratik toplumlarda önemlidir. Bu metodun, kendine has avantaj ve dezavantajları vardır.

c) Dinden Öğrenme (Learning from Rcligion): Bu öğrenme biçiminde, din sadece araştırma konusu değil, eğitimin konusu da olmaya başlar. Amaç, öğrenciye herhangi bir dini ya da mezhebi öğretmek değil, yaşama ilişkin değerleri ögrenmesini sağlayarak onun ahlâkî ve manevî gelişimine katkıda bulunmaktır. Bu modelde amaç, çocuğun eğitimi ve disipline edilmesidir. Bu scbeple, bu yaklaşım din eğitimi olarak da isimlendirilebilir.

Küreselleşmenin neticesinde sermayenin de küreselleştiğini, ekonomik değerlerin sosyal ve kişisel hayata her geçen gün daha fazla girdiğini söyleyen Hull, bildirisini bu problemin çözümüne yönelik şu önerileriyle bitirdi: "Ekonomik rekabetin fertler ve toplumlar üzerinde sebep olduğu olumsuzluklar, ancak manevî değerlere dönmekle ve bu konuda yapılacak işbirliği ile ortadan kaldırılabilir. Böylece din ve din eğitimi için, artık dinlerin birbirlerine karşı rekabetçi başarılar veya kendi içinde değerli sayılan geleneklerinin aktarımı peşinde koşmayan yeni bir rol ortaya çıkmaktadır. Dinin manevî ve ahlâkî değerlerinin küreselleşen sermaye değerlerine meydan okumasının, gençlerin ve yetişkinlerin yaşamlarına yeni bir yön ve anlam kazandırmakta gerekliliği farkedilmektedir. Bu yeni din eğitimi modeli, inançlar arası diyalog bağlamında ve Avrupa aydınlanmasının eleştirel ve laik varsayımları çerçevesinde sürdürülmelidir. Bu şartlarda Türkiye'nin Avrupa Birliği'ne girmesi, bu topluluğun dinî çoğulcu yapısına büyük bir güç katacaktır."

Oturumun ikinci bildirisi, Almanya Tübingen Üniversitesi'nden katılan Prof. Dr. Karl Ernest Nipkow tarafından sunuldu. Konu, "Avrupa Birliği Anlayışı Çerçevesinde Almanya'da Din Öğretimi" idi. Bildirisine, Avrupa Konseyi Bildirisi'nde, her bireyin dinî özgürlüğünün tanındığını, din eğitiminin bireyin hakkı olduğunu, bu hakkın devletin haklarından önce geldiğini, bu sebeple din öğretiminin düzenlenmesinin üye ülkelerin insiyatifine bırakıldığını belirterek başlayan Nipkow, tavsiye edilenin, din öğretiminin dinsel hoşgörü çerçevesinde verilmesi, hoşgörüye dayanmayan hedeflere ve amaçlara sahip bir ders olarak verilmemesi olduğunu söyledi. Nipkow'a göre, başkalarının dinine saygı, bireyin kendi dinini iyi ve doğru öğrenmesinden geçer. Bunun için de din öğretiminin genel müfredatın bir parçası olması gerekir. Ancak müfredatta tek bir inancın ya da dinin ön plana çıkarılması yerine, tüm dinlere eşit mesafede durulması ve tüm dinlere eşit fırsatın tanınması gerekir. Din eğitiminin nasıl kurumsallaştırılacağına ve düzenleneceğine dair üç ayrı modelden bahseden Nipkow, bu modelleri genel hatlarıyla şöyle açıkladı: a) Geleneksel Din Eğitimi Modeli: Bu bir bilgi disiplini olarak Hrıstiyan mezhepleri (Katolik-Protestan ve Ortodoks) ilahiyatının öğretildiği modeldir. b) Dinî Çalışmalar Modeli: Bu güncel modelde, bir bilgi disiplini olarak "Dinî Çalışmalar" başlığında bütün 
öğrencilere, tüm temel dinlere girişi kapsayan bir konunun sunulduğu modeldir. c) Entegre / Din-Felsefe-Ahlâk kurallarının birlikte öğretildiği model: Bu model, Federal Almanya'da birinci model değiştirilerek geliştirilmiştir. Devlet kilisesi feshedilmiştir, ama devletle dinî topluluklar birbirinden kesin çizgilerle ayrılmamışıır; katı bir laiklik söz konusu olmamıştır. Anayasal olarak din özgürlüğü tanınmıştır. Genel olarak ülkeler tarafından din özgürlügü ya "pozitif din özgürlüğü", ya da "negatif din özgürlüğü" şeklinde benimsenmiştir. Almanya bu ikisini birleştirmiştir. Olumsuz yönü, dinsel açıdan nötr olan devletin yurttaşlarına herhangi bir dini empoze etmekten kaçınmasıyla sonuçlanmasıdır. Olumlu yöne gelince, dinî topluluklara, Hrıstiyan, Müslüman ve Yahudilere kendilerine ait din eğitimi verme imkanını sağlamasıdır. Nipkow, Almanya'da din öğretiminin temel özelliklerini şu şekilde belirlemektedir: Almanya'da bütün öğrencilere din eğitimi verilir. Devlet bütün dinlere eşit muamele yapar. Din eğitimi vermek zorunlu, seçilmesi intiyaridir. Öğrenci Katolik ya da Protestan din eğitimini seçmek durumundadır. Tüm okullarda İslam da öğretilir. Dini öğretenler uzman kişilerdir. Tarafsız bir şekilde öğretmeye çalışırlar. Din dersinde öğretilenler, diğer sosyal bilimlerle ilgili derslerle desteklenir ve birbiriyle çelişmemesine dikkat edilir. Aile çocuğuna dinin öğretilmesine karşıysa, öğrenciye baskı yapılmaz. Din eğitimi almak istemeyenlere Ahlâk eğitimi verilir. Ahlâk dersi seçenlere de müfredat gereği biraz din öğretilir. Dinlerarası uyum ve müfredatı belirleme, dinlerin kendilerine bırkılmıştır. Protestan sınıflarına diğer mezhep ve din mensubu öğrenciler de kabul edilir. Her kişinin teolojik bireyselliğinin olduğuna inanılır. Hedef Hrıstiyanlığı yaymak değil, dinî bilgileri geliştirmektir. Bu sebeplerden dolayı, Din eğitimi çok boyutlu bir metodoloji içerisinde ele alınmalıdır. Doğruyu arama yönünde bir teolojik eğitim gerekir. İlahiyat, ruhu özeleştiri olarak kullanılırsa, Fundamentalizme götürmez. Eğitime dayanan dinî eğitimle İlahiyat'a dayanan dinî bir öğretim faydalı olur.

Oturumun "Almanya'da Dinî Çoğulculuk ve Okulda Dinlerarası Öğretim İçin Öneriler" adlı üçünçü bildirisi, Almanya'dan katılan Dr. Reinhard Kirste tarafından sunuldu. Dr. Kirste, Almanya'da dinî çoğulculuğun tarihinin, Avrupa'da $1555^{\prime}$ ten itibaren halk göçlerine kadar gerilere götürülebileceğini, özellikle Prusya döneminde bir çok inanç muhacirlerinin Branderburg'a kabul edildiğini, Hrıstiyanlar arasında uzun süre devam eden mezhep çatışmalarının yaşandığını, bu dönemlerde Müslüman doğunun Avrupa kültürüne önemli etkiler yaptığını belirttikten sonra şunları söyledi: "I. Dünya savaşından sonra diyalektik bir teoloji benimsenmiştir. Buna göre Hrıstiyanlık gerçek dindir, diğerleri gerçek din değildir. 1960' h yılların başına kadar İslam, tamamıyla dolaylı bir rol üslendi. Bu tarihlerden itibaren, başta Türkiye'den olmak üzere, diğer müslüman ülkelerden bugün sayıları 3-4 milyonu bulan müslüman nüfus Almanya'ya geldi. Hatta Avrupa'nın her tarafına işci göçü yaşandı. Katolik Kilisesi II. Vatikan Konsili'nde dinlerarası diyalog fikrini kabul etti. Aslında 
dinî çoğulculuk durumu, teolojik durumun, dolayısıyla Hrıstiyan'lığın mutlakiyet yetkisinin yeniden gözden geçirilmesini gerektirmiştir. Katoliklerin yer almadığı Ekümenik Kiliseler de, 1979'da bu tartışmalara katıldı ve Diyalogun ilkelerini belirledi. Ancak, Katolikler ve Protestanlar arasında diyalog problemi aşılamamıştır. Her iki tarafın da dogmatiklik iddası söz konusudur ve asla kendilerini reforme etmeye yanaşmamaktadırlar. Bu da Hrıstiyan teolojisini sınırlamaktadır. Sömürgecilik dönemi sona ermesine rağmen, "misyonerlik perspektifi" her ikisinde de, hala devam etmektedir. Bu arada üç farklı yaklaşım ortaya çıkmıştır. a) Kilise dışında yahut Hrıstiyanlık dışında kurtuluş yoktur. (Exklusivismus) b) Kesin ve garantisi olmasa da, diğer dinlerde de kurtuluş vardır. (Inklusivismus) c) Kurtuluşa giden Hrıstiyanlık yolu dışında önemli olmayan başka kurtuluş yolları da vardır. (Religious Pluralizm) "

Dr. Kirste göre, bu gelişmelerin neticesinde 1989 yılında yapılan toplantılardan sonra 50 civarında üyesi olan bir "Dinlerarası Çalışma Grubu" oluşturularak diyalogun eğitim kurumlarına yansıtılmasının gereği üzerinde duruldu. Aslında Dinlerarası Eğitim'in arkasında, dinlerarası diyalog çalışmaları bulunmaktadır. Böyle bir eğitim modelinin hedefi, hoşgörü ve uzlaşma düşüncesinin desteklenmesidir. Dinlerarası eğitimin önünde pek çok engellerin bulunduğunu belirten Dr. Kirste, bunların aşılabilmesi için şu yönlendirici ilkelerin benimsenmesini istedi: a) Diyalog, ancak eşit ortaklar arasında anlamlı bir şekilde gerçekleşebilir. b) Başkalarını kendi dinine döndürme anlayışından (misyon) vazgeçilmelidir. c) Dinlerin hükümranlık tezleri, ancak kendi inançlarının taahhütlerine dayanabilir. d) Hiç bir din en son gerçeği ortaya koyamaz. e) Dinler, kurtuluşa ermenin farklı yolları olarak algılanmalıdır. f) Okullarda çok kültürlü ve çok dinli bir hava oluşmuş̧ur. Bu sebeple din eğitiminde pedogojik yaklaşım da farklı olmalıdır. g) Dinler veya mezhepler, okulları ne kendi ilgi alanlarının uzantısı yapabilirler, ne de kendilerini yasal yetiştirme görevi dişında tutabilirler. h) Eğitim, bir mezhebin ya da dinin eğitimi değil, mezheplerüstü ya da dinlerarası bir eğitim olmalıdır. Dr. Kirste, bütün bu gelişmelere rağmen, dinlerarası bir eğitimin gerçekleşmesinin önünde, başta dinlerin örgütlenememesi ve temsil edilememesi problemleri olmak üzere, pek çok engelin bulunduğunu ve dinlerarası işbirliğini gerektirdiğini belirterek konuşmasına son verdi.

Oturumun dördüncü bildirisi, Norveç'ten katılan Dr. Kari Flornes tarafından sunuldu. Dr. Flornes, " Çoğulcu Toplumların Okullarında Zorunlu Din Ögretimi" adlı bildirisinde, Norveç'in 1997 yılında Din Dersi'nin zorunlu bir ders olarak kabul etmesinin gerekçelerini ve bunun sonuçlarını analiz etti. Din eğitiminin, zorunlu kılınmasının, çoğulcu toplum yapısına geçiş süreci, ulusal Hrıstiyan kültürü, insanların mezhep ögretilerinden uzaklaşması ve laiklik gereği yapıldığnı belirten Dr. Flornes, zorunlu din dersinin amacını şöyle açıkladı: " Çoğulcu bir toplumda zorunlu okul dersi olarak din eğitimi, her bir öğrencinin benlik duygusunu, kültürel bağlılığını 
devam ettirmek ve aynı zamanda paylaşılan bir kültürdeki diyalogu ilerletmek için yeni öğretici yaklaşımlar gerektirir. Bu yaklaşıma göre, geleceğin öğretmenleri, karşılıklı hoşgörü, saygı, ihtimam, eşitlik, adalet, destek ve empati temeline dayanan bir doğrudan iletişimli öğrenme ortamında bilgilerini, yeteneklerini ve ahlâklarını geliştirmeye zorlanacaklardır. "Dr. Flornes, bu dersin zorunlu kılınmasindan sonra öğrenciler üzerinde çeşitli araşıırmalar yapıldığını ve bu araştırmalarda bu dersi verebilecek ve öğrencilerin ihtiyaçlarını karşılayacak öğretmenlerin önceden yetiştirilmiş olmamasından dolayı, öğrencilerin çeşitli dinleri öğrenmekle biraz kafalarının karıştığını, ancak ailelerin dinin öğretilmesinden memnun olduklarının ortaya çıkı̆̆ını söyledi. Dr. Flornes, bu iki yıllık zorunlu eğitimin genel sonuçlarını şöyle sıraladı: a) Yöntem tuttu ve sevildi. Ögrenciler çok ilgi duyuyorlar. Hem kendi dinlerini, hem de farklı dinleri öğrenmekten memnunlar. b) Bireyler, bir bütün olarak eğitiliyorlar. c) Manevi Zeka ve Duygusal Zeka birlikte işliyor. d) Bu yöntemin, hem öğrenciler, hem de öğretmenler için faydalı olduğu anlaşıldı. e) Iyi öğretmenler tarafından verildiği takdirde, öğrencilerin şiddete ve disiplinsizliğe yönelmelerinin engellendiği görüldü. f) Öğrencilerle birlikte çalışmanın gereği ortaya çıktı. g) İnsanların ve öğretmenlerin gelecekteki manevi gelişimine katkı sağlamanın gerektiği anlaşıldı.

Bildiriler üzerine yapılan müzakerelerde, çoğulcu toplumlarda din öğretiminin, küreselleşen sermayenin ve ekonomik değerlerin yayılmasından doğan zararların önlenmesinde nasıl bir rol oynayacağı, zorunlu din ögretiminin gerckçeleri ve çoğulcu toplumlarda bir model olup olamayacağı, dinlerarası yöntemin dinlerarası diyalogla ilişkisi tartışıldı. Ayrıca dinlerarası eğitimde, özellikle müslümanların temsili ve kimin muhatap alınacağı konusunda ve öğretmen yetiştirilmesinde hala büyük problemler bulunduğu dile getirildi.

\section{Oturum: Din Öğretiminde Dinlerarası Yöntem}

"Din Öğretiminde Dinlerarası Yöntem"in tartışıldığı ve Prof. Dr. Beyza Bilgin'in başkanlığını yaptığı II. Oturum'da, ilk bildiri Hollanda'dan katılan Dr. Marien von den Boom tarafından sunuldu. Dr. von den Boom, "Kültürler Arası İletişimde Yeni Yönelişler" adlı bildirisinde, küreselleşme manasındaki globalizasyon'un ekonomi alanındaki kültürel etkileşimi artırdığını ve bunun sonucunda yerel değerlere dönüşü ifade eden glokalizasyon durumunu ortaya çıkardığını, böyle bir durumun din öğretimi alanını da etkilediğini vurgulayarak din eğitimin kaçınılmaz bir duruma geldiğini şöyle açıkladı: "Ekonomik alanda satın alma psikolojisinde kültürel faktörler nasıl önemli ise, din eğitimi verilirken de yerel değerlere ağırlık vermek o kadar önemlidir. Ancak bu, küresel kültür değerlerinin ihmal edilmesini gerektirmez. Zaten günlük hayatta bu değerlere dünyanın her tarafında rastlanmaktadır. Kültürler içinde paradoks gibi görünen birbirine zıt değerler bulunabilir. Bunları iyi yorumlamak gerekir. Nihai 
değerler ile ara değerleri iyi tespit etmek gerekir. Din eğitimi konusunda yerel değerleri tespit edenleri ve onların ait oldukları kültürlerdeki merkezi hususları iyi kavramak gerekir. Çünkü bu eğitimde, merkez sembolleri çok önemlidir. Bu sebeple din eğitiminde metodolojik yaklaşım üzerinde ciddiyetle durulmalı ve özellikle çoğulcu yaklaşım öne çıkarılmalıdır. Neticede ortak bir platform oluşturarak bunun içerisinde yerel kültürel değerler yerini almalıdır. "

Kendi ülkesinde çocukların dinî eğitimi konusunda henüz ortak bir kanaatin oluşmadığını, felsefî tarz da mı yoksa masal ve hikayclerle anlatılarak $\mathrm{m}$ verilmesi gerektiğinin netleşmediğini belirten Dr. von den Boom, anlamın bir aracı olarak hikayeler ve sembollerle dinin ögretilmesini savunmaktadır. Bu konudaki görüşlerini şöyle açıkladı: "Din öğretiminde uygulanabilen bu hikaye türü ve sembolik yaklaşım, laik ve çoğulcu toplumlardaki din öğretimi için bir alternatif olabilir. Anlamın ve insan sorgusunun sembolik bir yaklaşımı, farklı bir gerçekliğe açılış ve köprüdür. Çoğul gerçekliğin sembolik yaklaşımında, dinsel hayal gücünün ön gereği olarak örflerin ve sembollerin evrensel modelinin varlığı gereklidir. Bu, modern insan tarafından üzerinde çalışılmaya değer bir modeldir. Sembol, küresel dünyada, modern insanın dinî yönclişine yardımcı olur. Sembolik yaklaşım, din eğitimin çoğulcu ve çok uluslu bir toplumun ihtiyaçlarına uyarlamak için önemli bir araçtır. Sembolik öğrenim, aynı insanî sorunlar karşısında farklı kültürlerde farklı cevaplar bulunabileceğinin farkedilmesini sağlar." Dr. von den Boom, böyle bir yaklaşımın başarısını, çoğulculuğun dikkate alınmasına, çocukların din eğitimi almasının serbest bırakılmasına ve bu dersi verecek öğretmenlerin kendilerine düşen büyük sorumluluk içerisinde, bütün dinlere eşit mesafede durmalarına bağlamaktadır.

Oturumun ikinci bildirisi, Hollanda'dan katılan Prof. Dr. Siebren Miedema tarafından sunuldu. Prof. Dr. Miedema, "Dinler Arası Öğretim İhtiyacı" adını taşıyan bildirisinde, Hollanda eğitim sisteminde din eğitiminin mezhebe dayalı özel okullarda ve devlet okullarında farklı çerçevelerde verilmesinin pek çok soruna sebep olduğunu, bunu aşmanın yolunun, dinlerarası din eğitimi modeline geçiş olduğunu savundu. Bildiri sahibi, toplumların dinlerarası din eğitimine ihtiyaçın kaçınılmaz olduğunu şöyle gerekçelendirdi: "Okullarda sıkı kurallarla verilen geleneksel din eğitimi toplumlardaki farklılıkları artırmıştır. Mezhep merkezli din öğretimi sebebiyle ortaya çıkan büyük çalkantılar yüzünden, ABD'de din eğitimi ders programlarından çıkarılmışıı. Farklı dinlere/mezheplere dayalı bu eğitimin kaldırılmasıyla, bir çok aile bu eğitimi almadan yetişmiştir. Diğer taraftan, küreselleşme kapsamında toplumsal işlevini kaybeden dini, bulunduğu bireysel alandan kurtarmak gerekir. Çünkü günümüzde din, sadece bireyin hayatına girebiliyor. Halbuki kamusal yönü dolaylı olan dine, bütün toplum sistemlerinde yeni bir görev verilmiştir. Bu sebeple sekülerleşme, mutlaka dinsel çoğulculuğu kapsayacak şekilde ele alınmalıdır. Okul, bütün bu faaliyetlerde en önemli iletişim aracıdır. Farklı kültürler hakındaki bilgiler 
bir kişiye dengeli tarzda verilmelidir. Sömürgecilik zihniyetinden kurtularak yeni bir dünyanın kurulmasına gayret edilmelidir." Ampirik ve normatif bir düşünce çizgisi temelinde dinlerarası eğitim ihtiyacından yana bir talepte bulunan Prof. Dr. Miedema, din eğitimin özel amacının, insanın gelişmesine katkı sağlamak ve öğrencilere eleştirel yaklaşımı kazandırmak olduğunu, okul ortamında mezhep/din bağlamında değil, tarafsız verilmesi gerektiğini, bunun da dinlerarası bir modelle sağlanacağını vurgulayarak konuşmasını bitirdi.

Bu oturumun üçüncü tebliği, Norveç'ten katılan Doç. Dr. Beate Borresen tarafından sunuldu. Borresen, "Sorgulayıcı Metod: Din Öğretiminde Norveç Yaklaşımı" başlıklı bildirisinde, Amerikalı Professor Mattex Lipman tarafından geliştirilen " Çocuklar İçin Felsefe " adlı yöntemden hareketle sorgulayıcı bir modelin gerektiğini savundu. $\mathrm{O}$, konuşmasına, Norveç'te Felsefenin din ve ahlâk eğitiminin bir parçası haline gelmeye başladığını, dinden daha nötür olması dolayısıyla aileler tarafından da benimsendiğini söyleyerek başladı. Norveç'te 1997 yılından itibaren din eğitiminde felsefenin ön plana çıtı̆̆ğ , eleştirel düşünce ve dinlerarası diyalogun gerektiği üzerinde duran Borresen; böyle bir metodun, dini hayattan bağımsız ve sıkıcı bir şekilde öğretmekten kurtaracağını söyledi. Bildiri sahibi, bu metodun uygulamasını ve sakıncalarını ise şöyle açıkladı: "M. Lipman'ın metodunda çocuğun kendi başına öğrenmesi esas alınmıştır. Bu amaçla yazdığı kitaplar, beş yaş grubundan yetişkinler gurubuna kadar, bütün öğrenme çağlarını kapsamaktadır. Bu metodda temel alınan hikayeler dışında, oyunlara, araştırmalara, derse başlarken sorulara da önem verilmektedir. Temel hareket noktası olarak alınan hikaye, öğretmen tarafından yüksek sesle okunarak öğrencinin bunun üzerine düşünmesi sağlanır. Öğrencilerin sorduğu sorular tahtaya yazılarak içlerinden en fazla dikkat çekenler sınıf ortamında tartışılır. Iş̧te bu aşamada felsefi eğitim devreye girer. Çocukların birbirleriyle daha iyi tartı̧̧abilmeleri için, oturma düzeni daire şeklinde düzenlenir." Bu metodun başarıya ulaşabilmesi için öğretmenin iyi bir felsefe tarihi eğitimi almış olmasını şart koşan Borresen, öğretmenin bu modeli uygularken dikkat etmesi gereken ve öğrenciye kazandırması gereken hususları ise şöyle açıkladı: "Öğrenciler, konunun işlenmesinden önce yeterli bilgi edinmiş olmalıdır. Öğretmen derste doğru cevabın değil, iyi cevabın takipçisi olmalıdır. Bu yaklaşımda, öğrenci kendisini keşfedecek, başkalarının da farklı düşünebileceğini öğrenecektir. $\mathrm{Biz}$, ögrencileri tanıyıp daha iyi anlamamız, doğru düşündükleri konularda onları desteklenmemiz gerektiğini öğreniriz. Öğrenciler, bazı dinî görüşleri benimserler veya bazı ahlâkî davranışlar sergilerler. Felsefe yapmayı öğrendikten sonra bunların doğruluğunu daha iyi test etme imkanı kazanır. Öğrenci tek bir doğru cevabın değil, en iyi doğru cevabın daima bulunması gerektiğini öğrenince, başkalarının cevabını küçümsemeyecek ve onlara saygıyı, başka bir deyişle dinî diyalogu öğrenecektir. Bu durum, onun çoğulcu bir topluma daha iyi uyum göstermesini sağlayacaktır. " 
Yapılan müzakerelerde, bildiri sahiplerinin ileri sürdükleri tezlerin felsefî, sosyolojik, dinî ve teolojik temelleri ve uygulamada karşılaşılan problemler tartı̧̧ıldı.

\section{Oturum: Din Öğretiminde Fenomenolojik Yöntem}

Başkanlığını Doç. Dr. Zuhal Cafoğlu'nun yaptığı III. Oturumun ilk bildirisi, İngiltere'den katılan Dr. John Shepherd tarafından sunuldu. Dr. Shepherd, "Fenomenolojik Yaklaşım: Din Öğretiminin Sorgulanması" başlıklı bildirisinde, dinlerüstü ya da mezheplerüstü fenomenolojik yaklaşımın, diğer dinlerin daha iyi anlaşılmasına yönelik bir metod olduğu tezini savundu. Dinlerüstü/Mezheplerüstü yaklaşımın, fenomenolojik yaklaşımla ilintili olduğundan ve bu yaklaşımın "paranteze alma" ve "empati" olmak üzere iki unsurdan oluştuğundan bahseden Dr. Shepherd, bu iki unsuru şöyle açıklamaktadır: Paranteze almak, kendi inançlarımızı paranteze alıp diğer dinler hakkında konuşurken tarafsız olmak ve kalıp yargıdan bağımsız olmak demektir. Başkalarının dinini onlara öğretirken, o dine mensup olanların perspektifini benimsemek önemlidir. Empati ise, diğer din mensuplarıyla iletişim içerisinde olmak, onlara hoşgörülü ve saygilı olmaktır. Belli bir mezhebi ya da belli bir dini odak edinmeyen yaklaşımın, hem yararları hem de olumsuz yönleri bulunduğunu söyleyen Dr. Shepherd, bazı yararlarını ve olumsuzluklarını şöyle sıraladı: a) Taraflı ve önyargılı yaklaşımı engeller. b) Diğer din mensuplarına karşı hoşgörü ve saygıyı artırır. Olumsuzluklarına gelince, "inançları paranteze alma" ve "empati", bir diğer dini, o dinin mensuplarının yazdığı ve inandığı kaynaklara başvurmayı ve onların bakış açısıyla, yani "içerden birisinin gözüyle" (insider) bakmayı gerektirir. Bu bakımdan, dinlerüstü/mezheplerüstü bakış açısı, bazı olumsuz sonuçlar doğurur. "İçerdekilerin" görüşüne sorgulamasız yaklaşım ve atfedilen imtiyaz ü̧̧ açıdan eleştirilebilir: a) "İçerdekiler", kendi dinleri hakkında gerçek ve orjinal bilgi sunabilir, ancak bunların o dinin ne kadar gerçek temsilcileri olduğu tartışılabilir. b) "İçerdekiler", dini idealleştirme tuzağına çabuk düşebilirler. c) "İ̧̧erdekiler", her zaman en iyiyi bilir demek yanlıştır. İçerdekilerin bakışına fazla imtiyaz tanımak, onların ön yargılarını kendi dindaşlarının önyargılarının yerine koymak demektir. Bu sebeple içerdekilerin bakış açılarının çoğulculuğuna dikkat edilmelidir. Sadece olumlu yaklaşımlara değil, olumsuzlara da yer verilmelidir. Bu hem gerçekçi, hem de dürüst bir tutum olacaktır. Ayrıca "İçerdekilerin" görüşleri sorgulanmadan kabul edilmemelidir. İdealleştirilmeye karşı dikkatli olunmalıdır. Dr. Shepherd, din/mezhep merkezli yaklaşım için de eleştirel, fenomenolojik bakış açısının merkeze alınması gerektiğini iddia eder. Çünkü din/mezhep merkezli yaklaşımın (Confessional), eleştirel olan veya olmayan iki türü vardır. Eleştirel olan, diğer dinlere adil davranır. Idealleştirmeyi engeller. Bu yöntemde de, empati ve kendi inançlarını paranteze alma yaklaşımlarından yararlanmak mümkündür. 
Oturumun ikinci bildirisi, Hollanda'dan katılan Dr. Cok Bakker tarafından sunuldu. Dr. Bakker, "Din Öğretiminde Çeşitlilik " adlı bildirisinde, dinlerarası veya kültürlerarası din öğretimi kavramı yerine, "Çeşitlilik" kavramının kullanılmasının daha doğru olduğunu savunmaktadır. Dr. Bakker'e göre, "Çeşitlilik" bir okulda ya da sinıfta bulunması gereken bir özelliktir. Öğrenciler ve öğretmenler, bir takım değişkenlerden ötürü birbirlerinden farklıdır. Belirli bir guruptaki arkaplan, değişkenlerden sadece birisidir. Farklı gurupların olduğu çoğulcu toplumlardaki okullarda, din tek ve zorunlu bir tanımlama değişkeni olarak kullanılmamalıdır. Dinin yanısıra cinsiyet, yaş grubu, etnik özellikler de alt gurupların tanımlanmasında kullanılabilir. Değişken "din" veya " dini arka plan" içindeki bu çeşitliliğin, uzunca bir farklı değişkenler listesine bağımlı olduğunun farkında olmak gerekir. Her bir değişkenin kendi içinde çeşitliliği vardır. Değişken dini ya da değişken kültürü kendi bağlamından ayırmak yanlıştır. Bu yüzden çocukların eğitiminde, sadece dine vurgu yaparak ve yoğunlaşarak din öğretimi yapılmamalıdır. Bütün değişkenleri gözönünde bulunduran Dr. Baker, dine yeni bir yaklaşım getirmektedir. Bu yaklaşıma göre din, sadece geleneksel bakış açısından değil, bireyin aklındaki öznel ve zihinsel yapı olarak ele alınır. Bu sebepten kültürlerarası ya da dinler arası kavramlar yerine "çeşitlilik" kavramını kullanmayı önerir. Kamu veya dinî karakterli özel okullardaki öğrencilerin, çeşitli kültür ve geleneklerden geldikleri için, tek bir geleneğe dayalı düşünceler sisteminden ziyade birden fazla gelenekten etkilenerek büyüdüklerini belirten Dr. Bakker'a göre, verilecek eğitimin de bu çeşitliliği bütünüyle yansıtması gerekir. Bunu gerçekleştirmenin yolu, öğrencilere bir dinî kavramın, sadece o dinin mensuplarına değil, diğer mensuplarına da ne ifade ettiği öğretilmelidir. Dinî öğretilerin birden fazla yorumlanabileceği ve bunu yapabilmenin yollarını keşfetmeyi de çocuklara öğretilmelidir.

Oturumun üçüncü bildirisi Hollanda'dan katılan Dr. Ina ter Avest tarafından sunuldu. Dr. Ina ter Avest, "İlköğretim ÇocukIarının Sorgulayıcı Dinî Gelişimi (Ibrahim Peygamber Örneği)" başlıkhı bildirisinde, Semavî dinlerde ortak olarak anlatılan $\mathrm{Hz}$. İbrahim hikayesinden hareketle, din ögitiminde kıssaların ilkokul çocuğunun gelişim evresine uygun bir şekilde nasıl kullanılacağını tartışmakta ve bu konuda bir model ileri sürmektedir. Dr. Ina ter Avest, din öğretiminde yararlanılacak kıssaların çok iyi seçilmesi ve bu kıssaların açık ve gizli anlamlarıyla din öğretiminde kullanıldığı takdirde dinleyen ögrencileri olumlu adımlar atmalarında, insan, tabiat ve Tanrı ile iletişim kurmalarında motive edeceğini savunmaktadır. Ona göre, hikayenin açık anlamıla gizli anlamı arasındaki fark başlangıç noktası olarak alınır. Açık anlamın, dinleyicilerin günlük deneyimleriyle bağlantılı olarak önemli ölçüde değiştiğini, ancak gizli anlamının, dinleyicinin hayatındaki belirli bir andaki önemli temel deneyimlere kısaca değindiği görülür. " Değer biçme teorisi (Kıssadan hisse çıkarma )"nden hareketle, bu hikayeyi dinleyen kişiyi kendi hayatını kurgulayan ve anlattığı hikayeye 
katılan anlatıcı olarak görür. Dr. Ina ter Avest, bu teorisi çerçevesinde gelişen ve kişiye kendi hayatının temasını ortaya çıkarmasında yardımcı olan pratik bir metod, yani " kendisiyle yüzleşme metodu"nu gösterir. Bir gurp öğrenci ve yetişkin üzerinde yapılan araştırmada, "kendisiyle yüzleşme metodunun" uyarlanmış bir biçimi, İbrahim kıssası ile ilgili olarak kullanılmıştır. Bu araştırma, dinleyicilerin kıssalardaki açı ve gizli anlamları çıkarmalarında yaşlarıyla ve gelişmişlik düzeyleriyle ilişkili olduğu görülmüştür. Ayrıca kıssaların büyüklerin yardımıyla çocuklardaki eleştirel düşünce ve sorgulama yeteneğini geliştirdiği görülmüştür. Öğretmenler, bu sorglamay yapmalıdırlar ve ilköğretim düzeyinde din ögretiminde çocukların kıssaların görünen ve gizli anlamlarını anlayabilmeleri için onların seviyelerine göre kıssaları yeniden düzenlemelidirler. Bu uyarlama çocukluk sonrası dönemdeki öğrenciler için de geçerlidir. Bu şartlara uyulduğu takdirde, dinî kıssalar, çocuklara bazı rol modelleri sunabilir. Çocuk kendisini hikayedeki kahramanın yerine koyarak bilişsel ve fiziksel yeteneklerini geliştirebilir. Bağımsızlık ve başarı duygularını olumlu yönde etkileyebilir.

Yapılan müzakerelerde, din eğitiminin insanın sosyalleşmesi ve sağlıklı dindarlığın geliş̧irilmesinde daha iyi nasıl katkıda bulunacağı ve Fenomenolojik din eğitiminin felsefî eleştiri noktasına kaymaktan nasıl korunabileceği ile ilgili problemler tartışıldı.

\section{Oturum: Din Öğretiminde Doktriner Yöntem}

Başkanlığını Prof. Dr. Süleyman Hayri Bolay'ın yaptığı IV. Oturumun ilk bildirisi Almanya'dan katılan Prof. Dr. Johannes Laehnemann tarafından sunuldu. Prof. Dr. Laehnemann, "Doktriner Din Öğretimi Bağlamında Dinler Arası Ö̆gretim İlkeleri" adlı bildirisinde, din/ mezhep merkezli din öğretimi modelinde karşılaşılan problemler ve bunların aşılabilmesi için geliştirilen dinlerarası öğretim ilkelerini ortaya koydu. Almanya'da din derslerinin Anayasının 7. maddesinin 3. fıkrası gereği, dinî cemaatlerin ilkeleri ile uyum içerisinde yürütüldüğünü, bu sebeple dinî cemaatlerin din derslerinin içeriğinden sorumlu olduklarını, devletin de bu derslerin pedagojik normlara ve işlenen konuların devletin demokratik düzenine uygun olup olmadığını denetleme hakkının olduğunu söyeleyen Prof. Laehnemann, Almanya'daki Protestan ve Katolik mezheplerine göre verilen din derslerinin, toplumun çok dinli ve çok kültürlü bir topluma dönüşmesi sebebiyle, dinlerarası öğretim ilkeler gözönünde bulundurularak verilmesi gerektiğini ileri sürmektedir. Bu temel ilkeleri şu şekilde belirlemektedir: a) Din dersleri, modern ve çoğulcu dünyada herkesin dinî inanç ve gelenekleriyle barışık olmalarını sağlamalı, onların günlük yaşamlarına uygun olmalı ve yaşamlarının şekillenmesinde inançlarını yardımcı bir öğe olarak görmelidir. Geleneksel ögretileri tekrarlamak yetmez; çocukların hayatı ve tecrübeleriyle ilişkiye sokulması gerekir. b) Dünya dinleri hakındaki bir dersin amacı, sadece kendi ülkesini gözönünde bulundurmamak, dinlerin ve kültürlerin 
birbirleriyle ilişkili olduğunu, birbirini etkileyebileceği ve sorgulayabileceğini ciddiye almak olmalıdır. Din dersleri, çocukların diğer dinler ve kültürlere hoşgörülü, açık bir anlayışla yaklaşmalarına olanak vermelidir. c) Dünya dinleri sadece din derslerinin konusu olamamalı, dinle ilgili konuların gündeme geldiği Tarih, Coğrafya, Sosyal Bilimler, Müzik ve Sanat eğitimi gibi diğer branşların da konusu olmalıdır. d) Dinlerin özü sorgulanmamalı ve kendi geleneksel bakış açısıyla diğer dinler hakkında hüküm verilmemelidir. Prof. Dr. Laehnemann'a göre, bu şartalara uygun verilen din derslerinde, öğrenciler dinî kanaatlerin çokluğunda kendi inançlarını daha iyi anlama imkanı elde eder. Böyle bir din eğitimi modelinin de problemleri vardır. Çocuklar ailesinden veya çevresinden dinî konularla karşılaşmamışlarsa, kendi dinlerini ve diğer dinleri nasıl tanıtmak gerekir ? Mensubu olmadı̆̆ bir dini, bir öğretmen nasıl ortaya koymalıdır? Büyük dinlerin, gerçeklik iddialarını ve temel unsurları nasıl verilecek ? Bu poroblemler, din eğitimcileri ve bilim adamları arasında işlenmeli ve çözüm yolları bulunmalıdır. Prof. Dr. Laehnemann, bu problemlerin öğrencileri önyargı bariyerleri ile yüklenmemiş ve daha çok birbirini işitme ve öğrenmeye imkan veren bir karşılaşma durumuyla donatmak suretiyle aşılacağına inanır. Bunun için de, ilkokul birinci sınıftan başlayarak 10 . sınıfa kadar verilmesi gereken konularla ilgili geliştirdiği bir ders programını örnek olarak sundu. Bu programda, karşılıklı öğrenmenin birbirbirini tamamlayan bir süreç olduğunu, bu sürecin şu aşamalardan oluştuğunu söyledi:

1-Karşllıklı tanışmak,

2-Karşılıklı anlaşmaya,

3-Karşılıklı saygıya,

4-Karşllıklı öğrenmeye,

5-Karşılıklı fedakarlığa götürür.

O'na göre bu süreç tekrar karşılıklı tanışmaya ve aynı sürecin yeniden tekrarlanmasina sebep olur.

Oturumun ikinci bildirisi, Almanya'dan katılan Prof. Dr. Raimund Hoenen tarafından sunuldu. Prof. Dr. Hoenen, "Doktriner Din Öğretiminin Problemleri ve Almanya'nın Doğu Eyaletlerinde Din/Ahlak Ders Gurupları" başlıklı bildirisinde, 40 yıllık kesintiye uğrayan Doğu Almanya'daki din eğitiminin, her iki Almanya'nın birleşmesinden sonra bu bölgelerde ahlak ve din eğitimi olarak nasıl şekillendiği problemini tartışmaktadır. Prof. Dr. Hoenen, Doğu Almanya toplumunun ve özellikle gençliğin toplumsal, dinî ve kültürel durumunu analiz ettikten sonra şöyle bir sonuca varır: Ateist bir dönemin getirdiği dine olumsuz bakış açısı hala tesirini sürdürmektedir. İnsanlar, dine inanmayı bir ihtiyaç olarak görmemektedirler. Kilisesiz bir toplum haline gelmişlerdir. Dinî olanın artan biçimde kişiselleştirilmesi söz konusudur. Bu da dinin, topluma ve okula ait bir şey olarak değil, bireye ait bir şey olarak algılanmasına sebep olmuştur. Özellikle gençler Hrıstiyan değerleri reddediyorlar. Buna rağmen mezhepsiz ve dinsiz gençler din 
dersini seçiyorlar ve otantik olarak bilgilenmek istiyorlar. Bu konuda gençler yaşlılardan daha duyarlıdırlar. Gençlerin, Eğitim, Sanat, Tarih ve Müzik derslerinde dinle karşılaşmaları dinî öğrenmeye ilgilerini artırıyor. Son on yılda gençler arasında kilise ve dinden bağımsız dogmatik olmayan bir maneviyat gelişmeye başlamıştır. Bunun için de din ve ahlâk dersleri, gençlerin olumlu yönde gelişen maneviyatlarını ciddiye almak zorundadır. Prof. Dr. Hoenen, okullar için din öğretiminde önerilen üç ayrı modelin ortaya çıktığını söyler: a) Tüm öğrenciler için düzenli olmayan bir din dersi b) "Hayat Bilgisi-Ahlâk ve Din Dersi" bir branş olarak bütün öğrenciler için genel bir ahlâk-din dersi eğitimi c) Mezheplere dayalı bir din dersinin ve ahlâk eğitiminin farklı düzenlemlerle bir branş gurubu olarak düzenlenmesi. Mezheplere dayalı bir din öğretiminin problemleri olduğunu kabul eden Prof. Dr. Hoenen, bu modeli şu şekilde temellendirmektedir: a) Okulda davranış ve yaşantıya göre düzenlenen bir öğrenme biçimi, somut olarak yaşanan bir dini dikkate almalı ve kendini otantik olarak onun deneyimlerine dayandırmalıdır. b) Öğrencileri esas alarak düzenlenen bir öğrenme biçimi, yaşam ve değer yargılarının çeşitliliği dahilinde bir şekillendirmeyi ve düzenlemeyi taleb eder. c) Farklılıklara hitab eden öğrenme şekli, hem mezhepler ve dinler arasında, hem de dünyaya bakış açıları arasında bir diyalog ve işbirliğini gerektirir. Bu nedenle okullarda branş gurupları ve ders müfredatları dahilinde, aynı konularda birbirine entegre olarak ve ayrı ayrı verilebilen programlar ve ortak projeler geliştirilmelidir.

Oturumun üçüncü bildirisi, Almanya'dan katılan Prof. Dr. Reinhold Mokrosch tarafindan sunuldu. Prof. Dr. Mokrosch, "Almanya'da Doktrinler Arası Din Öğretimi: Tespit, Analiz ve Değerlendirme" başlıklı bildirisinde, günümüz modern ve seküler toplumların dinî bilgi boşluklarını, en sağlıklı bir şekilde Doktrinlerarası/Mezheplerarası bir din öğretimi modeliyle giderilebileceğini savunmaktadır. Almanya'daki Alman Hrıstiyan gençler ve Türk müslüman gençler üzerinde yaptığ 1 karşılaştırmalı analizlere dayanarak, bu iddiasını kısaca şu şekilde temellendirmektedir: Son otuz yıl içerisinde Almanya'da Protestan ve Katolik mezhepler arasındaki kesin çizgiler günlük hayatta yavaş yavaş kaybolmaktadır. Insanlar, kilise merkezli bir dindarlık yerine, kileseden bağımsız bir din anayışını benimsemektedirler. Eski geleneksel mezhep kalıpları günümüz insanının ihtiyaçlarına cevap vermemektedir. Günümz insanının dinî ihtiyaçları mezheplerin sınırlarını zorlamaktadır. Bu durum, Hrıstiyanlığın bütününü kapsayan ya da en azından mezheplerüstü bir Hrıstiyan din eğitiminin oluşturulması için olumlu nedenler sağlamaktadır. Gençler üzerinde yapılan sosyolojik araştırmalar sonucunda ortaya çıkan olgular, din psikolojisi, ilahiyat ve eğitim-kuramsal fenomenler bu fikri desteklemektedir. Ancak Roma Katolik kilisesi buna karşı çıkarken, Lutheryenler bunu desteklemektedirler. Herşeye rağmen mezhepler birliğine dayalı din eğitimi Almanya'nın her yerinde uygulanmaktadır. Hem Katolik, hem de Protestan gençlere ortak dersler verilmekte ve onların inançlarını güçlendirmeye 
yönelik, tamamıyla yeni metodlar denenmektedir. Prof. Dr. Mokrosch, mezheplerin birliğine dayalı bir eğitimin uygulamasının, aynı zamanda Hrıstiyanlar, Müslümanlar ve Hinduları kapsayan bir din eğitimi modeline dönüştürülebileceği ve bunun Türkiye için bir model olabileceğini düşünmektedir.

Oturumun dördüncü bildirisi, Cezayir'den katılan Prof.Dr. Hayrullah Assar tarafından sunuldu. Prof. Dr. Assar, "Cezayir'de Din Öğretimi: Orta Ögretim Ders Kitapları Üzerinde Bir İnceleme" başlıklı tebliğinde, Orta ögretimin birinci yılında okutulan din dersi kitaplarının, Cezayirli öğrencilerde dinde aşırılığı teşvik ettiği varsayımını, ders kitaplarından hareketle, test etmeye çalışmaktadır. Prof. Dr. Assar'a göre, bu kitaplarda, içeriğginin hazırlık sorularından, konuların işleniş biçimine ve örnek okuma metinlerine varıncaya kadar İslam dinini bağnazca vurgulama eğilimi hakimdir. Ayrıca Uluslararası orgnizasyonların rolleri hafife alınmaktadır. Öğretmenlerden içeriğin öğretilmesinde akılcı bir yaklaşım sergilemeleri istendiği halde, ders kitaplarındaki dogmatik eğitim yönelimi açıktır. Bu, bir açıdan laiklerle diğer taraftaki gelenekçiler arasındaki anlaşmazlık iddiasının (Fransız yanlıları ve komünistlere karşı Arap yanlıları ve İslamcılar) Cezayir'de çok belirgin olduğunu doğrulamaktadır. Prof. Dr. Assar, okutulan kitaplardan hareketle, Cezayir'de orta ögrenimin birinci yılında verilen İslamî eğitimde, yeterli ve dengeli bir yaklaşım ve 11 ımlı eğilimin olmadığını iddia etmektedir. Bu yüzden o, bugünkü Cezayir'de yaşanan bunalımın sebeplerinden birisi olarak bu din eğitimi modelini göstermektedir.

$\mathrm{Bu}$ oturumun müzakerelerinde, din ve mezhep merkezli din eğitimi modelinin günümüz insanının dinî ihtiyaçlarını karşılamakta bazı önemli problemlere sebep olduğu ve post modern/sekülerleşen bir dünyada dinlerüstü/mezheplerüstü birleştirici din eğitiminin geliştirmesi konusunda ileri sürülen görüşler tartışıldı.

\section{Oturum: Türkiye'de Din Öğretimi Yöntemi}

1924 'ten sonra Türkiye'de Din Ögretimi, genel eğitim içerisindeki yeri, modeli, programı, uygulamalar, yapılan değişiklikler, özellikle son zamanlarda yapılan program çalışmaları ve diğer ciddi değişiklikler üzerinde duruldu. Oturum başkanı Prof. Dr. M. Sait Yazıcıoğlu, son yıllarda din ögretimi alanıda yapılan İlahiyat Fakülteleri programları ve İmam-Hatip Liseleri'nin müfredat programlarının yenilenmesi, İlkokul ve Ortaokul Din Kültürü ve Ahlak Dersi müfredat programlarının değişmesi ve Ilahiyat Ön Lisans programının hayata geçirilmesi gibi önemli değişikliklere kısaca değindikten sonra ilk sözü Doç. Dr. Recai Doğan'a verdi.

Doğan, "1980'e Kadar Türkiye'de Din Öğretimi Program Anlayışları" başlıklı bildirisinde, 1924-1980 yılları arasında din öğretiminin tarihçesi ve bu dönemde din derslerinin genel eğitim sistemindeki yeri, bu dersle ilgili program anlayışları ve amaçları üzerine tespit ve analizler yaptı. Program 
geliştirme sürecinin tanımı ve eğitim sistemindeki önemi, vurgulayarak başlayan Doğan, ferdin ve toplumun ihtiyacını karşılayacak bir eğitim programını hazırlama sürecinin, ülkenin önem verdiği ve eğitim sistemine de yansımış olan değerlerle başladığını, bunların eğitimin çerçevesini, amaçlarını ve yöntemini belirlediğini söyledi. Program tasarımında, çocuğun psikolojik ve zihinsel gelişim çağları, çocukların ihtiyaçları, toplumun ihtiyaçları ve gelecekte nasıl bir görünüm kazanması gerektiği konusunun dikkatten uzak tutulmaması gerekir. Çünkü birbirlerini karşılıklı olarak etkileyen bireyin ve toplumun ihtiyaçları birbirinden ayrılamazlar. Bunlardan hiçbirisi diğerine feda edilemez. Doğan, Cumhuriyet döneminde din dersleriyle ilgili ilk program çllı̧̧malarının 1924'de ilk mektep programı çerçevesinde başladığını belirttikten sonra şunları söyledi: . Bu programda din bilgisi, Kur'an-ı Kerim ve Din Bilgisi adıyla II. sınıftan itibaren haftada ikişer saat şeklinde verilmeye başlanmıştır. Lise kısmında bu derse yer verilmemiştir. Bu dersin içeriği Kur'an-ı Kerim'in nasıl okunacă̆ $1, \mathrm{~Hz}$. Peygamber'in hayatı ve diğer bazı bilgilerden oluşmaktadır. Ortaokul kısmında I. sınıfta abdest ve namazla ilgili bilgiler verilmekte iken, II. sınıfta Peygamber'imizin Mekke ve Medine dönemi ile ilgili bilgiler verilmektedir. Programın hedefi, İslam muhabbeti ve sevgisini çocukların kalbinde yaşatmak idi. Bu programda 1915 ve 1916 yıllarının özellikleri görülür. Bir geçiş programı özelliği taşır. Osmanlı dönemindeki din bilgisi dersinin müfredat programıla hemen hemen aynıdır. İlmihalci bir yaklaşım vardır. 1926 yılında İlköğretimde yapılan köklü bir değişiklik sonucu, din dersleri III. sınıftan başlatıldı ve haftada bir saate düşürüldü. Laikleşme sürecinin başlamasıyla birlikte, 1930 senesinde şehir ilkokullarına beşinci sınıfta, Perşembe günü öğleden sonra bir saat program dışı din dersi konmuştur. Köy ilkokullarında ise yine aynı gün, ancak program içerisinde seçmeli bir ders olarak yarım saat konulmuştur. 1938 yılından itibaren köy ilkokullarında, tekrar III. sınıftan itibaren Perşembe günleri program dışı olarak haftada yarım saat verilmeye başlanmıştır. Cumhuriyetin kuruluş yılları ve tek partili dönemlerde din bilgisi ve muhtevası ile ilgili değişikliklerin, Cumhuriyetle başlayan yeni toplum oluşturma çabasının bir sonucu olduğunu belirten Doğan, bu dönemde din kültürü ve ahlak bilgisi müfredat programlarındaki yönelişi anlayabilmek için Cumhuriyet inkalıbının ve inkilapçılarının, İslamlığa değil, Osmanlı saltanatına ve hilafetine karşı bir tepki olarak ortaya çıktığını, onların asıl amaçlarının ise dini sömürü aracı olmaktan çıkarıp olması gereken gerçek ve aslî fonksiyonuna döndürülmesi olduğunu anlamak gerektiģini ileri sürdü. Burada program geliştirme sürecinde belirtilen, bireyin psikolojik gelişim çağlarını dikkate almak yerine yeni oluşmuş bir toplumun ihtiyaçları ve dinin modernleşmenin önünde bir engel değil destek olması amacı gözetilmiştir. Bazı kimseler Laikliği dinsizlik olarak anlamışlarsa da, Cumhuriyetin müfredat programlarındaki anlayı̧ bu değildir. Din dersleri konusunda 1948 yılından sonra tekrar bazı değişikliklere gidildiğini belirten 
Doğan, bu konuda şunları söyledi: Hukukî değil toplumsal ve siyasal ihtiyaçlardan dolayı Din dersleri ilkokul IV. ve V. sınıftan itibaren seçmeli olarak programa alındı. Bu Laikliğe ters düşülmemesi adına ve İslam dininin temel öğretilerinin verilmesi adına yapıldı. 1950'de program içine alındı. 1949 'da din dersi isteyen kimselerin velileri dilekçe verirken, 1950'de istemeyen kimseler dilekçe vermiştir. 1968'e kadar aynı ders devam etmiştir. 1967 yllında isteğe bağlı olarak Lise I. ve Il. sınıfa din dersi konulmştur. 1976 da tekrar bir düzenleme yapılmıştır. Orta okul ve Lise'nin bütün sinıflarına Din kültürü ve Ahlak bilgisi dersleri isteğe bağlı olarak yaygınlaştırılmıştır. 1949 sonrası din dersi müfredat programlarının temel özellikleri ise şöyledir: Bu dönemde din dersi eleştirel doktrin merkezlidir. Dinden kaynaklanan ve modernleşmenin önüne engel olan şeylerin öğretilmesi vardır. Dini iyi kullanabilmesi için kişiye inandığını eleştirme imkanı veren bir zihniyeti getiriyor. Cumhuriyet döneminde, Din Kültürü ve Ahlak bilgisi derslerinde, Türkiye Cumhuriyeti'nde yaşayan insanların bir üst kimlikte birleştirilmeyi, amaçlayan bir din eğitimi yapılmıştır. Devletin hedefleri ön görülmüştür. Zamanla dindersinin muhtevası daraltılmıştır. Bilimsel verilerin 1şı̆̆ında ve program geliştirme ilkelerine göre yapılmamıştır. Demokratikleşme süreciyle beraber merkezileşmiştir. 1976 sonrasında, ferdî, sosyal, ekonomik ve evrensel ihtiyaçlar gözönüne alınmaya başlanmıştır. Sadece İslam değil, diğer dinlerle ilgili bilgilere de yer verilmiştir.

Oturumun ikinci bildirisi, Prof. Dr. Beyza Bilgin tarafından sunulmuştur. Bilgin, "1980 sonrası Türkiye'de Din Öğretimi Program Anlayışları" başlıklı bildirisinde, 1980 ihtilalinden sonra Türkiye'de Din Kültürü ve Ahlak Bilgisi derslerinin zorunlu bir ders olarak eğitim sisteminde yerini almasının anayasallaşması sürecini ele aldı. Türkiye'de ihtilal sürecine nasıl gelindiği konusunu kısaca açıkladıktan sonra, askeri yönetim döneminde din dersi ile ilgili çalışmalarla konusunda şu bilgileri verdi: Milli Güvenlik Koseyi, Türkiye'de yaşanan toplumsal ve siyaŝ̂ bunalımın kaynağını, eğitim ve öğretimde Tevhid-i Tedrisat'tan geriye dönüş olduğunu, tekrar birlik ve bütünlük içerisinde yaşayabilmek için eğitimde birliğin yeniden sağlanması ve Atatürkçülüğe dönülmesi gerektiğine inaniyordu. Bunun için 1980'de geniş kapsamlı bir komisyon kuruldu. 1981 'de bu çalışmalar sonuçlandı. Bu çalışmaların başladığı sırada, Prof. Dr. Hüseyin Atay MGK'na bir rapor verdi. Bu raporda kısaca, Türkiye'de din derslerinin, benim yaptığım çalışmaların sonuçlarına dayanarak, seçmeli olması dolayısıyla hep sorun olduğu, seçmeyen öğrencilerin okul dışına gittikleri ve disipline edilemedikleri gerekçesiyle, herkesin tarih ve diğer dersleri ögrendiği gibi bu dersi de zorunlu olarak okuması gerektiği ve bunun faydaları anlatıldı. MGK bu raporu ciddiye aldı ve kendisini dinledi. Daha sonra MEB'lığındaki komisyona Fakülte'den seçilecek bir kişinin müşahit olarak katılması istendi. Bunun için ben seçildim. Daha sonra başka Fakülte ve Enstitüler de aynı teşebbüslerde bulundu. Din Kültürü ve Ahlak 
Bilgisi dersinin kabulü ve mecburî oluşu şu üç aşamada gerçekleşti: a) Prof. Dr. Hüseyin Atay'ın Milli Güvenlik Konseyi'ne 1980 yılında sunduğu rapor b) MEB Din Eğitimi Çalışma Grubu c) MEB Din Eğitimi Danışma Kurulu. İlgili komisyonlarda ben, din derslerinin keyfi değil mecburî olması gerektiğini, Laikliğe aykırı olmadığını, Ahlak derslerinin, din dersine alternatif olmadığını ve din kültürünün herkes tarafından bilinmesi gerektiği konularında komisyon üyelerini bilgilendirmeye çalışıyordum. Bu arada, doktrin/mezhep merkezli din dersinin toplumu bölmeye götüreceği ve Laikliğe rağmen din dersi konulamayacağ ${ }_{1}$ şeklinde itirazlar oldu. Bu itirazlara karşı şöyle cevap verdim: Ülkemizde bazı mezhepler varsa, bunlar inkar edilemez. Mezhep merkezli yerine mezhepler arası din öğretimini öneriyorum. Bu derslerde bir mezhebin bilgisi değil din bilgisinin verilecek. Verilen din bilgisi kişiyi mümin yapması beklenemez. Bilmek ayrı şey, mümin olmak ayrı şey. Mezheplerarası bir din öğretimi, kişilerin birbirinin mezhebine saygılı olmasını öğretecek ve herkes kendi mezhebiyle iftihar edecek. Amaç, daha iyi müslüman olarak yaşamak. Laikliğe aykırılık meselesine gelince, bunun ne olduğunu tespit için de komisyon kuruldu. Ben, Türkiye'deki laikliğin bizim ülkemize has bir laiklik olduğunu, kanun ve yasama hakkının TBMM'ne verildiğini, Diyanet'in ise inanç, ibadet ve ahlâkî konularda halkın ihtiyacını karşıladığını söyledim. Komisyon raporları hazırlandı ve Kenan Evren'e verildi. Bu arada din dersinin leh ve aleyhinde bir çok haberler çıktı. Bunların bir kısmı Kenan Evren'e özel olarak uluştırılmıştı. Sonra bu konuda bir birifing verildi. Burada da pek çok şey söylendi. Ben de söz alıp bu dersin Mezheplerarası ve Dinlerarası verileceğini ve zorunlu olmasının faydalarını anlattım. Ertesi günü Meclis'te ele alındı ve eğitim sistemi içerisinde zorunlu bir ders olarak verilmesi yasalaştı.

Oturumun üçüncü bildirisi Prof. Dr. Cemal Tosun tarafından sunuldu. Tosun, "2000'li yıllarda Türkiye'de Din Öğretimi: Bugünden Geleceğe" başlıklı bildirisinde, son yıllarda Türkiye'de Din Öğretimi ile ilgili program geliştirme çalışmalar, özellikle de Din Kültürü ve Ahlak Bilgisi programları üzerindeki çalışmaları, bunun arka planı, çıkış noktaları ve hedefleri üzerinde durdu. 1980 öncesinde din öğretimi konusunda "varlık-yokluk" tartışmaları yaşandığı, bu tartışmaların bilimsel zeminlerde değil, siyasî zeminlerde siyasî amaç, bilgi ve söylemlerle yapıldığı tespitinde bulunan Tosun, din öğretiminin ancak 1980 yılından sonra bu kısır tartışmalardan kurtulduğunu, Din Eğitimi Anabilim Dalları adı altında geçekleştirilen bilimsel çalışmaların uygulama alanına doğru akışının başladığı ve bunun sonucunda program çalışmalarının başladı̆̆ını söyledi. Tosun, ikibinli yıllarda Din Öğretimi alanındaki gelişmeleri, İmam- Hatip Liseleri Öğretim programları ve İlköğretim Din Kültürü ve Ahlak Bilgisi Dersi Öğretim programlanı olmak üzere iki ayrı sahada yapılan değişiklikleri anlattı. Bütün bu değişmelerin kaynağında, Türkiye'de 1997 yılında "Sekiz Yıllık Kesintisiz Eğitim" uygulamasına geçişin bulunduğunu söyleyen Tosun, 
yoğun bir çalışma süreci sonucunda konusunda uzman kişilerden oluşan komisyonların, bu iki programı hazırladıklarını; birincisinin sonuçlandığını ikincisinin ise İlköğretim kısmının sonuçlanarak yürürlüğe girdiğini, programlarda hedeflenen kaliteyi yakalayabilmek için ilgili her kurum ve kişinin gereken katkıda bulunmaktan kaçınmaması ve özellikle İHL'ni etkileyen diğer hususlarda öncelikli tedbirlerin alınması gerektiğini belirtti. Bildirisinin ikinci bölümünde, Din Kültürü ve Ahlak Bilgisi programının bilimsel arka planını, hazırlanış sürecindeki temel mantık örgülerini, ilkelerini ve programın genel amaçlarını inceledi. Tosun, programın çıkış noktaları ve yaklaşım biçimi konusunda da şu bilgileri verdi: Programın hazırlanmasında konu merkezli yaklaşımdan mümkün olduğu kadar uzak durulmuştur. Bunun yerine öğrenciyi, toplumu, kültürü ve evrenseli nazarı dikkate alan sorun ve hedef merkezli bir yaklaşım benimsenmiştir. Genelde din, özelde ise İslam dini ve ahlâk, bu merkezî yaklaşım çerçevesinde göz önünde bulundurulmuştur. Türk Milli Eğitimi'nin amaçları, ile İlköğretim okullarının amaçları, duruma göre yönlendirici, sınırlayıcı veya bütünleyici olarak işlev görmüştür. Doğrudan din ve ahlâk alanından alınan konu ve hedefler ise, mutlaka öğrenci, toplum, kültür, evrensel, Türk Milli Eğitimi'nin amaçları ve ilköğretimin amaçları süzgecinden geçirilerek alınıp şekillendirilmiş ve ona göre yerleştirilmiştir. Ayrıca bu bildiride, programın hazırlanmasında gözetilen hedefler, öğrenme-öğretme sürecinde uyulması gereken ilkeler, uygulama ile ilgili açıklamalar ve genel amaçlara yer verildi. Genel amaçlar ise, bireysel, toplumsal, ahlâkî, kültürel ve evrensel açılardan analiz edildi. Bildirinin sonuç kısmında şu görüş̧lere yer verildi: İlköğretim Din Kültürü ve Ahlak Bilgisi dersleri öğretim programları, Milli Eğitimimizin yetiştirmek istediği insan tipinin din ve ahlâk boyutunu desteklemek için yapılmıştır. Laik-Demokratik ülkelerde okul herhangi bir dine mensuplar yetiştirmek için din öğretimi yapmaz. Bunun için okullardaki din ve ahlâk öğretiminin amac1, öğrencilerin bireysel, toplumsal, kültürel ve evrensel boyutlarda karşılaştıkları ve karşılaşacakları dinsel ve ahlâksal gerçeklerle insanî ölçütler içerisinde doğru, olumlu ve uygun şekilde başa çıkabilecek şekilde yetiştirmektir. Ancak, bu başa çıkmanın şekli bireylerin vicdanlarına kalmıştır. Kimisi dindar olarak başa çıkmayı tercih ederken, kimisi dinsiz veya dine ilgisiz kalarak başa çıkmayı tercih edebilir. Okuldaki din ve ahlâk öğretimi açısından önemli olan, ne şekilde olursa olsun, yapılan tercihin doğru öğrenmelere dayanmasını sağlamaktır. Dolayısıyla okuldaki din ve ahlâk öğretimi dindar olmak isteyene yeterli ögrenmeleri kazandırmak durumundadır. Buradaki esas amaç ise, bireylerin dinsel açıdan istismarının ve sömürülmesinin önüne geçmektir. Dindar olmak istemeyene veya dine ilgisiz kalana da din ile ilgili karşılaştıkları durumlarda insanî açıdan uygun ve doğru davranışları gösterebilecek öğrenmeleri kazandıracaktır. Buradaki amaç ise, din lehine veya aleyhine takınılacak tavırlardan ortaya çıkabilecek çatışma ve huzursuzlukları engellemektir. 
Yapılan müzakerelerde, Türkiye'de Din öğretimi yöntemi ve sorunlarıyla ilgili sunulan tebliğlerde ortaya atılyan fikirler tartışıldı.

\section{Genel Değerlendirme Oturumu:}

Başkanlığını Necdet Özkaya'nın yaptığı değerlendirme oturumunda, üç gün boyunca devam eden oturumlarda sunulan tebliğler ve bunlar üzerine yapılan müzakerelerde ele alınan konuların genel olarak özetlendiği raporlar, her oturumun raportörü veya oturum başkanı tarafından okunarak katılımcıların, dinleyicilerin ve basının dikkatlerine sunuldu. Bu sempozyum, Türkiye'de din öğretimi modeli geliştirme projesi çalışmalarına ışık tutması amacıyla düzenlendiğinden, bir sonuç bildirisi hazırlanmadı.

Bu sempozyum, din eğitimi konusunda önümüzdeki yıllarda uzun süre tüketilmeye devam edecek önemli bir malzemenin üretilmesine sebep olmuştur. Ayrıca bu sempozyumdan Türkiye açısından dikkate alınması gereken şu önemli sonuçlar çıkmıştır:

1) Din öğretiminin, çocuğun zihinsel gelişim evreleri, bireyin ve toplumun ihtiyaçları ve öğretilen dinin özgün yapısı dikkate alınarak yapilması,

2) Din Öğretimi'nde daha önce uygulanan mezhep merkezli modellerin, günümüz toplumlarının ihtiyaçlarını karşılayamadığı için, artık Mezheplerarası / Dinlerarası, Birleştirici veya Mezheplerüstü / Dinlerüstü yaklaşımların geliştirilmeye başlandığı,

3) Din Öğretimi'nin, toplumların çok kültürlü ve çok dinli yapıları gözönünde bulundurularak verilmesi,

4) Din Öğretiminin bireyin hakkı olduğu ve bunun din mensupları tarafından karşılanamadığı takdirde devletin bunu karşılaması,

5) Seküler ve post modern toplumlarda, insanların ferdi dindarlık şeklinde yeni bir dindarlık geliştirdiği ve din öğretiminin bu gelişmeye paralel olarak yeniden gözden geçirilmesi,

6) Din Öğretimi'nde ailelerin rolünün önemli olduğu,

7) Din Ögretimi'nin, sadece Din Dersleri'nde verilmemesi, diğer derslerle de desteklenmesi,

8) Din Öğretimi'nin varlık-yokluk tartışmalarından kurtulup hangi yaşta nelerin nasıl öğretilmesi gerektiğinin tartışılması,

9) Din Öğretimi yaşının Batılı ülkelerde ilkokul birinci sınıftan başladığı, Türkiye'de de bunun bilimsel zeminlerde araştırılması,

10) Din Dersleri ile ilgili geliştirilen modellerin başarıya ulaşabilmesi için bu derslerin mutlaka bu programaların uygulayıcıları olarak yetiştirilen kişilerce verilmesi,

11) Din Öğretimi'nin mutlaka bilimsel metodlarla öğretimin konusu olması,

Bu sempozyum, basın ve yayın organlarında çeşitli şekillerde değerlendirilmiş ve hakkında pek çok köşe yazarı yazılar yazmıştır. Üzülerek ifade etmek gerekirse, bir çoğu sempozyumun birinci günü Diyanet İşleri Başkanı'nın Kur'an Kursları ile ilgili bir teklifi üzerinde 
odaklanmış ve Sempozyum'da asıl tartışılan konuların kamuoyuna yansımasına engel olmuşlardır. Bu sebeple, üç gün süren bu sempozyumda sunulan tebliğlerin metinlerinin ve üzerine yapılan müzakerelerin bir an önce yayınlanmasının, akademik seviyede yeni tartışmalar başlatacağı ve din ögretimi konusunda ülkemizin yaşadığı sıkıntıların aşılmasında ve yeni modellerin geliştirilmesinde önemli katkılarda bulunacağı kanaatindeyiz. 